\title{
Agro-environmental project duration and effectiveness in South-east Asia
}

\author{
M. Subedi, M.A. Fullen, T.J. Hocking, \\ A.R. McCrea and E. Milne
}

\begin{abstract}
Considerable emphasis has been placed on developing technologies for agricultural sustainability. Many bilateral projects are working to achieve this outcome. A desk review was conducted to study the importance of project duration for the effectiveness of sustainable agricultural projects. Longer-duration projects were successful in addressing more holistic issues than short projects. However, funding agencies tend to fund shorter-duration projects, so projects become progressively shorter. At the same time, the number of projects implemented each year is increasing. Despite the decrease in total development assistance, increases in project numbers, particularly since 1986, appear to be at the cost of project duration. Short project duration was one of the most cited reasons for not completing essential dissemination activities for wider adoption, whereas longer-duration projects were usually considered more successful in addressing more holistic issues. It is difficult to produce tangible outputs from agricultural and soil conservation projects within five years. Considering the slow changes in the system and in agricultural and environmental sustainability, the authors suggest that project developers should be advised to plan for a minimum of 5-10 years, depending on the nature of activities. It is time for funding agencies to reconsider their tendency to fund shorter-duration projects.
\end{abstract}

Keywords: project duration; project effectiveness; sustainability

M. Subedi, M.A. Fullen, T.J. Hocking and A.R. McCrea are with the School of Applied Sciences, University of Wolverhampton, Wulfruna Street, Wolverhampton WV1 1SB, UK. E-mail: m.subedi@yahoo.com. E. Milne is with the Macaulay Institute, Craigiebuckler, Aberdeen AB15 8QH, UK.

Until the 1960s, the increasing demand for food in developing countries was mainly met by expanding the land area under cultivation. Between 1927 and 1960, there was a $40 \%$ increase in the total arable area in the world from 1 billion to 1.4 billion hectares (Evans, 1998). The world's population had reached three billion by 1960. Population has continued to grow and the rate of population increase was highest $\left(2.1 \%\right.$ year $\left.^{-1}\right)$ between
1965 and 1975 (Evans, 1998). This created an even greater demand for increased food production, particularly in developing countries, with most of the easily available land already in cultivation. The increasing gap between the total population and total food production imposed further pressures for producing more food and fibre from approximately the same land area (Bridges and Oldeman, 2001). In pursuit of satisfying food demand, people's 
activities focused on increasing production without due attention to the resultant effects (both short- and longterm) on natural resources. This is evident from the fact that humans today use $\sim 12,000$ times more energy, mainly in the form of fossil fuels, than they did 400 generations ago (Munasinghe and Shearer, 1995; Walmsley, 2002). As a result, per capita availability of usable resources has declined further, adversely affecting agricultural production (Pratap and Watson, 1994) and making the long-term viability of current agricultural systems doubtful (Rigby et al, 2001). This situation is more apparent in poor and developing countries, which depend more on natural resources for their income.

Environmental degradation and poverty generally go hand in hand, particularly in agricultural countries (Bie et al, 1997).

After 1960, increasing emphasis was placed on crop intensification involving new cultivars and increased use of fossil fuel, fertilizers, chemicals and machinery. Scientists were able to modify the morphology and physiology of crop varieties through plant breeding, making them more responsive to high inputs. This led to a dramatic increase in the use of chemical inputs in agriculture. The combination of high-yielding cultivars and high inputs formed the basis of the 'green revolution' (as described by the USAID Administrator, W.S. Gaud in 1968; Evans, 1998). However, high production goals were prioritized without appropriate consideration of the resultant wider effects of such production techniques. As a result, production systems in different parts of the world witnessed various problems associated with land degradation, soil erosion, water pollution and resource depletion (Lal et al, 1988; Pratap and Watson, 1994; Evans, 1998; Hurni, 2000; Röling, 2005).

As these problems were identified, there was increasing awareness of the need for more sustainable, environmentally friendly cropping practices (Agenda 21, 1992). Therefore, in the last 25 years, agricultural development projects in developing countries have primarily focused on two key objectives: first, continuing the increase in production/productivity of food crops to meet an increasing demand for food; second, improving the sustainability of cropping systems by reducing the adverse impact of intensification and conserving natural resources (Wills et al, 1987; Gerpacio, 2001; ICRISAT, 2002; IRRI, 2003; CIMMYT, 2004).

Substantial resources have already been invested to generate technologies for more sustainable agricultural intensification in developing countries. For example, official international assistance for agricultural development alone was $>\$ 9,000$ million year ${ }^{-1}$ during the 1980 s and 1990s, even reaching \$13-14,000 million year ${ }^{-1}$ during 1982-86 (Trotter and Gordon, 2000). As a result, there were significant improvements to agricultural technologies, which for the most part were more effective in increasing production and productivity than existing technologies. However, many of these new technologies considered to be 'effective' have been less successful in alleviating the associated sustainability problems (Tang Ya, 1999; Neupane et al, 2002; McKemey et al, 2003). We have therefore reviewed past projects implemented to improve agricultural sustainability in South-east Asia in terms of their effectiveness.

\section{Review of effectiveness of sustainable agricultural projects implemented in South- east Asia}

There is a clear distinction between sustainable agricultural initiatives on flat and sloping land. Land with a $\geq 35 \%$ gradient is categorized as sloping land, which is vulnerable to rapid topsoil loss in response to agricultural practices (Sombatpanit, 2001). Steep gradients favour rapid overland flow, which increases soil loss and decreases soil moisture retention. Thus, sloping lands generally have shallow soils, low organic matter content and poor moisture retention. Topsoil loss often decreases productivity and usually decreases nutrient supply (Sajjapongse, 1992). Hence initiatives for flat land have focused on improving fertility status and soil biological properties, while on sloping land efforts have focused on reducing soil, water and nutrient losses by reducing runoff and thereby erosion. Consequently, land degradation and desertification have decreased along with an improvement in fertility status and soil biological properties (Nutalaya, 1991; Pratap and Watson, 1994; Tang Ya, 1999).

Considerable efforts have been made, from both research and development perspectives, towards the sustainable management of sloping land in Asia (Sajjapongse, 1992; Pratap and Watson, 1994; Maglinao et al, 1995; van Keer et al, 1998; Tang Ya, 1999). Most of the sustainable development programmes/projects on the sloping uplands of South-east Asia had one or more of the following objectives: conserving natural resources, reducing soil and water erosion, improving/maintaining soil fertility; improving crop production and food security; and achieving rural development. Such programmes/projects were implemented under one or more of the following thematic programme areas:

\section{Highland development programmes}

Much work has been done to improve the natural resources of the tropical highlands of Asia, particularly in Thailand and Vietnam. Highlands are arbitrarily defined as the ecozone above $500 \mathrm{~m}$ altitude (van Keer et al, 1998). Agriculture in highland areas is characterized by subsistence and shifting cultivation practices, which involve large-scale clearing of the natural vegetation and subsequent cultivation on steep to very steep slopes (van Keer et al, 1998). Soil and water erosion is one of the main problems in the highlands of South-east Asia. In addition, widespread opium production and consumption by highland tribes have not only posed health risks, but have also threatened regional security. Agricultural development and natural resource management programmes were often linked with narcotics control programmes, thereby resulting in collaboration between unusual and apparently unrelated disciplines, such as agricultural development and narcotics control.

\section{Sloping land and natural resource management programmes}

Two international institutions: namely, the International Centre for Integrated Mountain Development (ICIMOD, based in Nepal) and the International Board for Soil 
Research and Management (IBSRAM, based in Thailand), have given high priority to achieving greater sustainability on sloping lands. ICIMOD started to test and demonstrate sloping agricultural land technology (SALT) with particular emphasis on contour hedgerow technology from 1991 (Pratap and Watson, 1994; ICIMOD, 1999; Tang Ya, 1999). This system is being increasingly studied and tested in many countries. IBSRAM developed 'sustainable land management' (SLM) technologies with particular emphasis on different crop combinations for alley cropping systems and on developing a framework for evaluating SLM projects (Dumanski et al, 1991; Sajjapongse, 1992; Maglinao et al, 1995; Sajjapongse and Elliott, 1995; Sajjapongse and Leslei, 1998). The soil conservation and sustainable agriculture programme in the Loess Plateau of China gave greater emphasis to restoring vegetation cover in order to increase rainwater infiltration and decrease soil-water movement in the vast bare area of the Plateau (Liu Guobin, 1999).

\section{Food security, poverty alleviation and rural development programmes}

Addressing food security and poverty is essential to achieve rural development goals in the target area. Furthermore, overexploitation of natural resources leading to land degradation is often blamed for the poverty of local residents. This can be recognized by the fact that rural development and natural resource management programmes have placed considerable emphasis on addressing rural poverty by increasing on-farm and/or off-farm income-generating enterprises to improve the livelihoods of the rural poor (Do Thi Ngoc Oanh et al, 1997; ADB, 1999; Liu Guobin, 1999; Monschein, 1999; Evans and Sophana, 2004). The international crop research programmes of CGIAR are focusing on generating technologies for improving crop productivity to achieve food security and, thereby, the sustainability of agricultural systems (Wills et al, 1987; Gerpacio, 2001; ICRISAT, 2002; IRRI, 2003; CIMMYT, 2004).

\section{Cropping system programmes/farming system programmes}

Most projects within 'cropping/farming system programmes' were implemented in poverty-stricken areas where subsistence farming systems were predominant. Most were implemented using cropping or farming system approaches to meet the needs of subsistence farming communities. Some projects, however, have been specifically dedicated to improving farming systems using a wide range of technologies, for example: 'Evaluation and Improvement of Farming Systems in the Mekong Delta' (Kokubun, 1998), 'Asian Grain Legumes On-Farm Research Project' (Gowda et al, 1996), 'Cambodia-IRRIAustralia Project' (Nesbitt, 1997), 'Improvement of the Sustainability of Cassava Based Cropping Systems in Asia' (Howeler, 1996).

These projects varied substantially in many aspects, such as the availability of resources, project duration, project area, activities implemented and effectiveness, and success. In this paper, we have laid particular emphasis on project duration in relation to the effectiveness of sustainable agricultural development projects.

\section{Materials and methods}

A desk survey studied changes in project duration over time. The information was sampled from the Development Gateway database (Development Gateway, 2003). The desk review was carried out during 2003. Sampling of projects from the database was done considering 'theme of project' and 'geographical location of its implementation', irrespective of donor countries and institutions. Projects implemented in South Asia aimed at sustainable agricultural and environmental development or related issues (such as food security, poverty alleviation, rural development, natural resource management, soil-water conservation) were selected for the study. Information on 719 projects, which started between 1970 and 2003, was abstracted for the analysis.

\section{Results}

Statistical analysis of the 719 projects implemented in South-east Asia showed that project duration ranged from 1-30 years, with a mean duration of 4.74 years (median $=$ 4 years and mode $=2$ years). Moreover, the duration of $585(81 \%)$ projects was $\leq 6$ years (Figure 1$)$. There was clearly a decreasing trend in the duration of projects over time. The duration of the later implemented projects was shorter compared with projects initiated earlier $\left(\mathrm{r}=-0.593^{* * *}, \mathrm{n}=719\right.$; Figure 2$)$.

Despite a clear trend of decreasing project duration, this trend required clarification between 1985 and 2003 (Figure 2). Hence, a separate statistical analysis was conducted for projects started between 1985 and 2003 (Figure 3). Despite the visually less obvious trend for the period between 1985 and 2003, the statistical parameters were similar to the overall trend for the period 1970-2003 $\left(\mathrm{r}=-0.468^{* * *}, \mathrm{n}=692\right)$. Duration of projects implemented during 1985-2003 ranged between 1 and 17 years, with a mean duration of 4.43 years (median $=4$ years and mode $=2$ years). The median value of 4 years seems to be linked to the political structure of Western democracies, as the duration of Western governments in major donor countries is generally $4-5$ years. Policies, strategies and priorities are likely to change with a change in government. This could be the reason for the $\sim 4$-year commitment from donor countries to sustainable development projects in developing countries.

The analysis also revealed that there was an increased number of projects implemented during the period from 1970-2003 (Figure 4). The number of projects implemented was particularly low up to 1986 compared with 1987 onwards. The average number of projects implemented during 1970-86 was 3.5 year $^{-1}$ (with median value of 3, mode 2 and range 1-8), while the average number of projects implemented during 1987-2003 was 40.2 year $^{-1}$ (median value 31 , mode 62 and range $2-118$ ).

Correlation analysis also revealed a significant association between time and the number of projects implemented $\left(\mathrm{r}=0.650^{* * *}, \mathrm{n}=719\right)$. However, a negative and statistically significant association was found between the number of projects implemented per year and project duration $\left(\mathrm{r}=-0.571^{* *}\right)$. Thus, results suggest that the increase in project numbers, particularly after 1986, was at the cost of project duration. 


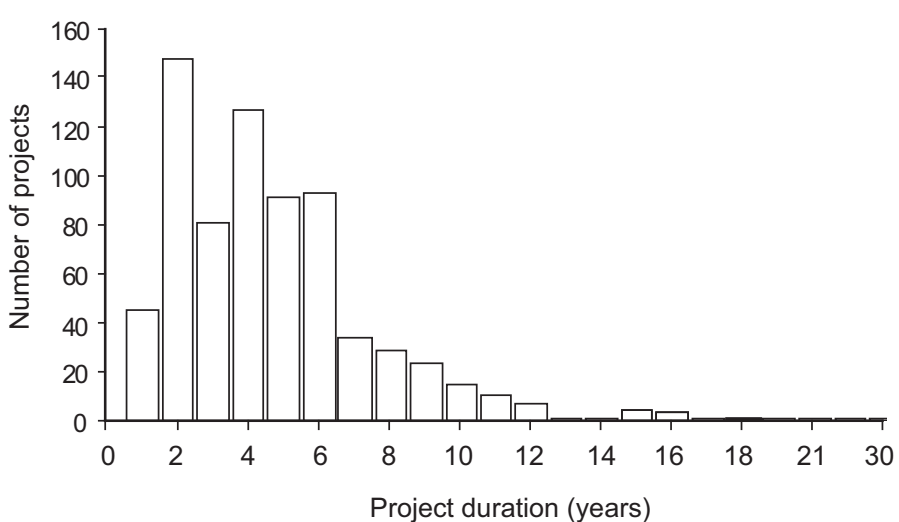

Figure 1. Duration of sustainable development projects $(n=719)$ implemented in South-east Asia, 1970-1999.

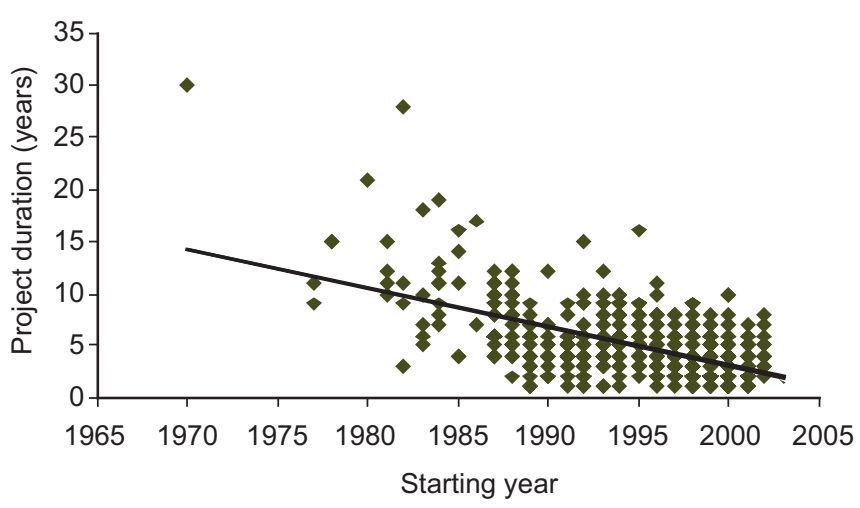

Figure 2. Duration of projects in relation to the year implemented.

Note: $R^{2}=0.351 ; p<0.001 ; \mathrm{n}=719$.

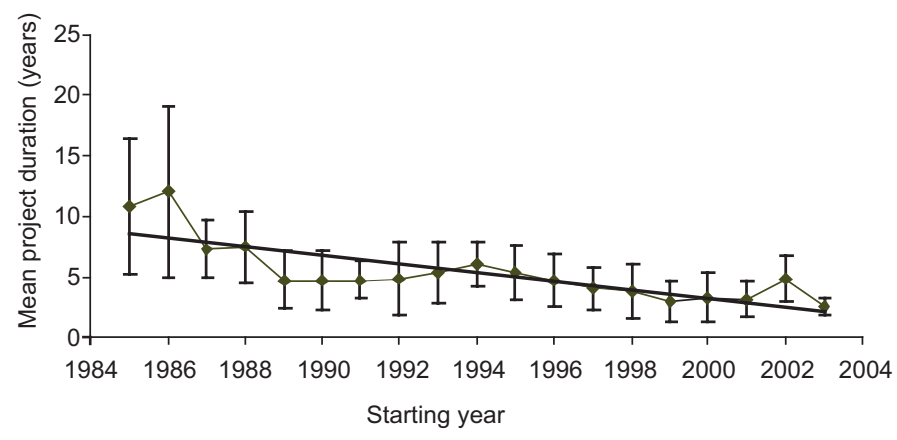

Figure 3. Mean duration of projects ( \pm 1 SD) started during 19852003.

Note: $R^{2}=0.638 ; p<0.001 ; \mathrm{n}=19$.

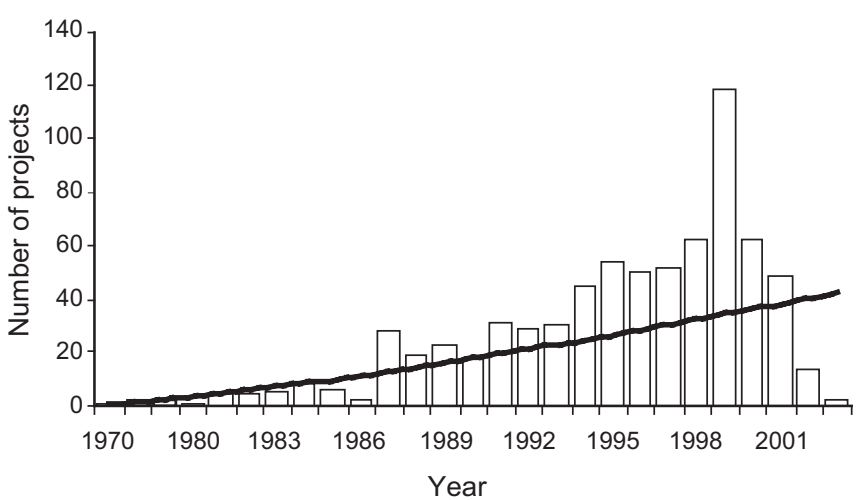

Figure 4. Number of projects implemented in South-east Asian countries, $1970-2003$.

Note: $R^{2}=0.609 ; p<0.001 ; \mathrm{n}=27$.

The numbers of projects funded by the UK, The Netherlands, Norway, Australia, Denmark, Canada and the World Bank were relatively greater than those funded by other countries/organizations. Analysis of Variance (ANOVA) revealed that project duration was significantly different between the funding countries/organizations $\left(\mathrm{F}=10.92^{* * *}, \mathrm{n}=436\right.$, Table 1). Similarly, Indonesia, Nepal, China, Vietnam, The Philippines, Cambodia, Malaysia, Thailand and Laos received comparatively more projects than other recipient countries in the region (Table 2).

\section{Discussion}

The results reveal that funding agencies have inclined towards funding shorter-duration projects. This is not an encouraging development, as short-duration projects often fail to achieve or demonstrate effective and sustainable change. Several authorities have recognized that at least five years are required to produce tangible outputs from conservation projects (SUAS, 1990).

Considering the tendency of agricultural systems to change slowly, Hudson (1991) suggested planning a 10year horizon as a norm for such projects.

Official development assistance to agriculture in developing countries decreased from US\$13,000-14,000 million year ${ }^{-1}$ during 1982-86 to US\$9,300 million in 1996 (Trotter and Gordon, 2000). Similarly, agricultural assistance per capita of population in the least developed countries fell by almost 50\% between 1982 and 1995. In addition, the trend in agriculture's share of total funding fluctuated and declined from 33\% to 19\% between 1980 and 1996 (Trotter and Gordon, 2000). Similarly, PinstrupAnderson and Pandya-Lorch (1998) reported a declining trend in total official assistance to both overall and agricultural development. Such a declining trend in international assistance to agricultural development in developing countries could be one of the reasons for the reduction in project duration over time. Moreover, such a trend forces developing countries to accomplish their goals with less assistance.

There were fewer (but longer-duration) projects in the past compared with more (but shorter-duration) projects at present. Despite the decrease in total development 
Table 1. Major donor countries for agricultural and environmental projects in South Asia, 1970-2003.

\begin{tabular}{|c|c|c|c|c|c|}
\hline Country & Number of projects & Mean project duration (years) & Std deviation & Std error & Range \\
\hline 1. UK & 261 & 4.36 & 2.10 & 0.13 & $1-15$ \\
\hline 2. The Netherlands & 39 & 3.08 & 1.66 & 0.27 & $1-7$ \\
\hline 3. Norway & 36 & 3.11 & 2.90 & 0.48 & $1-10$ \\
\hline 4. Australia & 28 & 3.75 & 2.24 & 0.42 & $1-10$ \\
\hline 5. World Bank & 25 & 7.60 & 2.48 & 0.50 & $4-16$ \\
\hline 6. Denmark & 15 & 3.40 & 1.30 & 0.34 & $1-5$ \\
\hline 7. Canada & 11 & 5.82 & 1.72 & 0.52 & $3-9$ \\
\hline 8. Germany & 5 & 8.60 & 2.07 & 0.93 & $5-10$ \\
\hline 9. Switzerland & 5 & 4.00 & 1.41 & 0.63 & $2-5$ \\
\hline 10. Sweden & 5 & 2.60 & 1.52 & 0.68 & $1-5$ \\
\hline 11. Austria & 4 & 3.00 & 1.15 & 0.58 & $2-4$ \\
\hline 12. Finland & 2 & 3.50 & 2.12 & 1.50 & $2-5$ \\
\hline Total & 436 & 4.30 & 2.38 & 0.11 & $1-16$ \\
\hline$F$ & & 10.92 & & & \\
\hline$p$ & & $<0.001$ & & & \\
\hline
\end{tabular}

Table 2. Major recipient countries of agricultural and environmental projects in South Asia, 1970-2003.

\begin{tabular}{clc}
\hline No & Country & Number of projects \\
1 & Indonesia & 154 \\
2 & Nepal & 136 \\
3 & China & 111 \\
4 & Vietnam & 62 \\
5 & The Philippines & 39 \\
6 & Cambodia & 33 \\
7 & Malaysia & 33 \\
8 & Thailand & 20 \\
9 & Laos & 14 \\
10 & India & 6 \\
11 & Bhutan & 5 \\
12 & Bangladesh & 4 \\
13 & Mongolia & 2 \\
& Total & 619 \\
\hline
\end{tabular}

assistance after 1986 (Trotter and Gordon, 2000), the funding agencies were able to fund more projects by reducing the duration of funding commitment. It is difficult to choose between fewer longer-duration projects and many shorter-duration projects. Choice of the former option would be at the expense of many important activities required for overall agricultural development, while the second option would decrease the number of long-term projects. The choice should be based on the nature of the activity. However, the predetermined criteria of funding agencies often force the recipient country/ organization to conduct longer-term activities too quickly. At present, there is a trend of preparing grant proposals to fit the criteria of funding agencies. Thus strategies adopted by funding agencies have paramount effects on the type and length of projects in developing countries.

Short-duration projects often fail to disseminate the outcomes in wider areas due to insufficient time, and identify dissemination as an area for future work (SUAS, 1990, 1991). In contrast, longer projects such as the 'ThaiGerman Highland Development Project (TG-HDP)' and 'Thai-Australian Highland Agricultural and Social Development (TA-HASD) Project', which lasted for 18 and 12 years respectively, were able to disseminate long-term activities and reported the impact of such activities on the living standards of target communities, farming systems and environmental condition of the target area (AusAID, 1999; TG-HDP, 1999; Dirksen, 2001, 2002). Longerduration projects are able both to commit more time to dissemination and to follow through the processes of adoption and adaptation and possibly achieve greater long-term success. Long-term and strong commitments of both funding agency and host government are very important to achieving such accomplishments from any international development assistance (Ruaysoongnern, 1999; Dirksen, 2002).

\section{Conclusions}

Despite the decrease in total development assistance, funding agencies, particularly since 1986, have tended to fund greater numbers of shorter-duration projects. It is the strategies adopted by funding agencies that are mainly responsible for the decreasing length of projects in developing countries.

Short project duration was one of the most cited reasons for not completing some essential dissemination activities that might have led to wider adoption, whereas longer-duration projects were usually considered as more successful in addressing more holistic issues. It is difficult to produce tangible outputs from agricultural and soil conservation projects within five years. Considering the slow changes in the system, agricultural and environmental sustainability projects are advised to plan for a minimum of 5-10 years, depending on the nature of activities. We propose that it is time for funding agencies to reconsider their tendency to fund shorter-duration projects. 


\section{Acknowledgments}

M. Subedi thanks the University of Wolverhampton for providing a research studentship to conduct this work.

\section{References}

ADB (1999), 'Poverty reduction and environmental management in remote Greater Mekong Sub-region (GMS) watersheds (Phase I): Final Report', Asian Development Bank, Website: http:/www.mekonginfo.org/mrc_en/doclib.nsf/0/ DB60A148CB7239EEC725683300275159/\$FILE/FULLTEXT.html

Agenda 21 (1992), Agenda 21, Program of Action for Sustainable Development, United Nations Publications, New York.

AusAID (1999), Targeting Poor Farmers: Contributions to Rural Development in Thailand, Quality Assurance Series No 16, The Australian Government's Overseas Aid (AusAID) Program, Website: http:/www.ausaid.gov.au/publications/pdf/ qas16_thailandfarmers.pdf.

Bie, S. W., Baldascini, A., and Tschirley, J. (1997), 'The context of indicators in $\mathrm{FAO}^{\prime}$, in Land Quality Indicators and their Use in Sustainable Agriculture and Rural Development, FAO, Rome.

Bridges, E. M., and Oldeman, L. R. (2001), 'Food production and environmental degradation', in Bridges E. M., et al, eds, Responses to Land Degradation, Science Publishers Inc, Enfield, $\mathrm{NH}$.

CIMMYT (2004), CIMMYT in Asia, International Maize and Wheat Improvement Center (CIMMYT), El Batan, Mexico, Website: http:/www.cimmyt.cgiar.org/worldwide/CIMMYT_Regions/ CIMMYT_Asia/cimmyt_in_asia/cimmyt_in_asia.htm.

Development Gateway (2003), 'AiDA - Accessible Information on Development Activities', Development Gateway Foundations, Washington, DC, Website: http://aida.developmentgateway.org/ AidaHome.do.

Dirksen, H. (2001), Considerations and Lessons from Implementing the Thai-German Highland Development Program (TG-HDP) in Northern Thailand, Thai-German Highland Development Program (TG-HDP), Website: http:/www.gtz-asia-online.org/ hdp/frame.htm?lib.nsf?OpenDatabase.

Dirksen, H. (2002), 18 Years of the Thai-German Highland Development Program - Has it Been a Success Story? German Technical Co-operation (GTZ), Website: http:/www.gtz.de/drogen/ download/english/publications/dirksen_02.pdf.

Do Thi Ngoc Oanh Le Am, Jussi Kauppi, and Aleksi Lehtonen (1997), Study on Agroforestry Systems and Soil Survey, Technical Report No 8, The Vietnam-Finland Forestry Sector Cooperation Program and the Department of Agriculture and Rural Development of Bac Kan Province, Website: http:/ www.mekonginfo.org/mrc_en/doclib.nsf/0/ 9279765061EA0ACC472568E90016516A/\$FILE/FULLTEXT.html.

Dumanski, J., et al, eds (1991), 'Evaluation for sustainable land management in the developing world. Volume 2: Technical Papers', IBSRAM Proceedings, Vol 12, No 2.

Evans, L. T. (1998), Feeding Ten Billion: Plants and Population Growth, Cambridge University Press, Cambridge.

Evans, P. T., and Sophana, V. (2004), 'Lessons from the "Participatory Natural Resource Management in the Tonle Sap Region" project', in Torell, M., Salamanca, A. M., and Ratner, B. D., eds, Wetlands Management in Cambodia: Socio-economic, Ecological, and Policy Perspectives, Technical Report 64, WorldFish Center, Penang, Malaysia.

Gerpacio, R. V., ed (2001), Impact of Public- and Private-Sector Maize Breeding Research in Asia, 1966-1997/98, International Maize and Wheat Improvement Center (CIMMYT), El Batan, Mexico.

Gowda, C. L. L., et al, eds (1996), Approaches to On-Farm Research in Asia: Summary Proceedings of the Regional Workshop on OnFarm Adaptive Research, International Crops Research Institute for the Semi Arid Tropics (ICRISAT), Patancheru, India.

Howeler, R. H. (1996), 'The use of farmer-participatory research methodologies to enhance the adoption of soil conservation practices in cassava-based cropping systems in Asia', in Sombatpanit, S., et al, eds, Soil Conservation Extension: From Concepts to Adoption, Science Publishers Inc, Enfield, NH.

Hudson, N. W. (1991), 'A study of the reasons for success or failure of soil conservation projects', FAO Soils Bulletin, Vol 64.

Hurni, H. (2000), 'Soil conservation policies and sustainable land management: a global overview', in Napier, T. L., Napier, S. M., and Tvrdon, J., eds, Soil and Water Conservation Policies and Programs: Successes and Failures, CRC Press, Boca Raton, FL.

ICIMOD (1999), Manual on Contour Hedgerow Inter-cropping Technology, International Centre for Integrated Mountain Development (ICIMOD), Kathmandu, Nepal.

ICRISAT (2002), 'This is ICRISAT', International Crops Research Institute for the Semi-Arid Tropics (ICRISAT), Patancheru, India, Website: http://www.icrisat.org/web/uploads/ presentations/07032003202810ThisisIcrisat.pdf.

IRRI (2003), 'Cambodia and IRRI', International Rice Research Institute (IRRI), Los Banos, The Philippines, Website: http:// www.irri.org/media/facts/pdfs/cambodia.pdf.

Kokubun, M. (1998), 'JIRCAS projects for the development of technologies for sustainable agriculture in Asia', in Horiuchi, H., and Tsubota, K., eds, The 4th JIRCAS International Symposium: Sustainable Agricultural Development Compatible with Environmental Conservation in Asia, JIRCAS International Symposium Series, Japan International Research Center for Agricultural Research, Tsukuba, Japan.

Lal, R., Miller, F. P., and Logan, T. J. (1988), 'Are intensive agricultural practices environmentally and ethically sound?' Journal of Agricultural Ethics, Vol 1, pp 193-210.

Liu Guobin (1999), 'Soil conservation and sustainable agriculture on the Loess Plateau: challenges and prospects', Ambio, Vol 28, No 8, pp 663-668.

Maglinao, A., et al, eds (1995), 'International workshop on conservation farming for sloping uplands in Southeast Asia: challenges, opportunities, and prospects', IBSRAM Proceedings, No 14, The International Board for Soil Research and Management (IBSRAM), Bangkok.

McKemey, K., et al (2003), Farmers' Attitudes Towards Land Management Strategies: A Theory of Reasoned Action Analysis, Working Paper 5, DfID NRSP project R7958, 'Developing supportive policy environments for improved land management strategies - Nepal', University of Reading, Reading.

Monschein, Y. (1999), 'Poverty reduction and food security in China: the Sino-German food security program Shandong', Agriculture and Rural Development, Vol 2, pp 61-63.

Munasinghe, M., and Shearer, W., eds (1995), Defining and Measuring Sustainability: the Biophysical Foundation, World Bank, Washington, DC.

Nesbitt, H. J., ed (1997), Rice Production in Cambodia, International Rice Research Institute, Los Banos, The Philippines.

Neupane, H., Ojha, H., and Garforth, C. (2002), Scaling Up of Sustainable Soil Management Practices: Case Studies of Panchkhal and Sanga Villages in Kavre District, Nepal, ForestAction, Kathmandu, and the University of Reading, Reading.

Nutalaya, P. (1991), 'Pollution and other off-site effects on sustainable land development', in Dumanski, J., et al, eds, Evaluation for Sustainable Land Management in the Developing World: Technical Papers, IBSRAM Proceedings, Vol 12, No 2.

Pinstrup-Anderson, P., and Pandya-Lorch, R. (1998), 'Food security and sustainable use of natural resources: a 2020 vision', Ecological Economics, Vol 26, pp 1-10.

Pratap, T., and Watson, H. R. (1994), Sloping Agricultural Land Technology (SALT): A Regenerative Option for Sustainable Mountain Farming, International Centre for Integrated Mountain Development (ICIMOD), Kathmandu.

Rigby, D., et al (2001), 'Constructing a farm level indicator of sustainable agricultural practice', Ecological Economics, Vol 39, pp 463-478.

Röling, N. (2005), 'Gateway to the global garden: beta/gamma science for dealing with ecological rationality', in Pretty, J., ed, The Earthscan Reader in Sustainable Agriculture, Earthscan, London. 
Ruaysoongnern, S. (1999), 'Adoption of sloping land conservation practices by farmers in the northeast of Thailand', in McDonald, M., and Brown, K., eds, Issues and Options in the Design of Soil and Water Conservation Projects, School of Agriculture and Forest Sciences Publication Number 17, University of Wales,

Bangor.

Sajjapongse, A., ed (1992), Technical Report on the Management of Sloping Lands for Sustainable Agriculture in Asia, Phase 1, 1988 1991 (IBSRAM/ASIALAND), Network Document No 2, International Board for Soil Research and Management (IBSRAM), Bangkok.

Sajjapongse, A., and Elliott, C. R., eds (1995), ASIALAND: The Management of Sloping Lands for Sustainable Agriculture in Asia (Phase 2, 1992-1994), Network Document No 12, IBSRAM, Bangkok.

Sajjapongse, A., and Leslei, R. N., eds (1998), ASIALAND: The Management of Sloping Lands for Sustainable Agriculture in Asia (Phase 3, 1995-1997), IBSRAM Proceedings No 23, IBSRAM, Bangkok.

Sombatpanit, S. (2001), 'Thailand's response to land degradation the need to control soil erosion', in Bridges, E. M., et al, eds, Responses to Land Degradation, Science Publishers Inc, Enfield, $\mathrm{NH}$

SUAS (1990), Evaluation of the Chinese-Swedish Soil Conservation Co-operation Project, Working Paper No 147, International Rura Development Department, Swedish University of Agricultural Sciences (SUAS), Uppsala.
SUAS (1991), Chinese-Swedish Soil Conservation Project 1987-1990: Final Report, International Rural Development Department, SUAS, Uppsala.

Tang Ya (1999), 'Factors influencing farmers' adoption of soil conservation programs in Hindu Kush Himalayan region', in McDonald, M., and Brown, K., eds, Issues and Options in the Design of Soil and Water Conservation Projects, School of Agriculture and Forest Sciences Publication Number 17, University of Wales, Bangor.

TG-HDP (1999), 'TG-HDP Human Resources Development Study. Thai-German Highland development program', Internal Paper No 188, Website: http:/www.gtz-asiaonline.org/hdp/ frame.htm?lib.nsf?OpenDatabase.

Trotter, B., and Gordon, A. (2000), 'Charting change in official assistance to agriculture', Food Policy, Vol 25, pp 115-124.

van Keer, K., et al, eds (1998), Options for Soil and Farmer Friendly Agriculture in the Highlands of Northern Thailand, Deutsche Gesellschaft für Technische Zusammenarbeit (GTZ) GmbH, Eschborn.

Walmsley, J. J. (2002), ‘Framework for measuring sustainable development in catchment systems', Environmental Management, Vol 29, No 2, pp 195-206.

Wills, J. B., et al, eds (1987), Coordination of Grain Legumes Research in Asia: Summary Proceedings of the Review and Planning Meeting for Asian Regional Research on Grain Legumes (Groundnut, Chickpea, and Pigeonpea), 16-18 Dec 1985, International Crops Research Institute for the Semi-Arid Tropics (ICRISAT), Patancheru, India. 